\title{
Problematização das Situações-limite no Contexto do Ensino e Formação em Ciências: Contribuições da Abordagem de Temas com Viés Freireano
}

\author{
Problematization of Limit Situations in the Context of Science Education \\ and Training: Contributions from Freirean Approaches
}

(D) Eril Medeiros da Fonseca, (D) Tassiéllen Soares Antunes Tadeu, (D) André de Azambuja Maraschin,

(D) Renata Hernandez Lindemann

\begin{abstract}
Palavras-chave Resumo $\mathrm{O}$ presente trabalho tem por objetivo identificar e Formação de problematizar situações-limite na perspectiva do ensino e formação Professores; de professores de Ciências, a fim de sinalizar possibilidades Contextualização; de enfrentamento na prática pedagógica. Realizaram-se Paulo Freire. aprofundamentos em resultados de três investigações que envolveram formação inicial de professores de Química, formação continuada de professores de Ciências e práticas no ensino de Química na Educação Básica. Destacam-se algumas limitações relacionadas ao trabalho pedagógico de professores e à percepção da realidade, que dizem respeito à organização curricular e ao planejamento didático, bem como em relação a limites para vislumbrar as potencialidades presentes no contexto local. Por isso, argumenta-se a favor de um ensino contextualizado, que considere aspectos da realidade local como forma de enfrentamento de situação-limite para uma formação crítica. Além disso, defende-se que os processos formativos sejam orientados por abordagem dialógica e problematizadora a fim de contribuir para romper com o silêncio e proporcionar a ressignificação da prática docente.
\end{abstract}


Keywords Abstract This paper aims to identify and problematize limit situations Teacher Training; in the perspective of teaching and training Science teachers, in order Contextualization; to explore possibilities of coping in pedagogical practice. Findings

Paulo Freire. of three investigations were analyzed, which involved initial training for Chemistry teachers, continuing training for Science teachers and practices in the teaching of Chemistry in Basic Education. Some limitations related to pedagogical aspects and perception of reality were found among teachers, which relate to curricular organization and teaching planning, as well as to the idea of exploring potentialities in the given context. For this reason, we argue in favor of a contextualized teaching, which considers aspects of the local reality as a way of coping with the limit situation for a critical training. In addition, training processes must be guided through a dialogical and problematizing approach in order to contribute to breaking the silence and providing a new meaning for teaching practice.

\section{Introdução}

As práticas escolares no Ensino de Ciências, no geral, ainda são pautadas por uma perspectiva de ensino focada exclusivamente nos conteúdos conceituais, priorizando o estudo de conceitos para provas e exames futuros. Busca-se, portanto, formas de superação dessas práticas que se constituem pela dissociação entre o que é estudado e vivenciado pelos estudantes, por meio de propostas pedagógicas coerentes com os ideais progressistas de educação, as quais priorizam a constituição da cidadania e a transformação da sociedade.

Alguns trabalhos (Delizoicov et al., 2011; Paniz et al., 2018) discutem possibilidades de articulação de uma prática de ensino contextualizada, que é pensada a partir do contexto. Tais possibilidades materializam-se por meio da abordagem de temas. Centa (2015) salienta que os temas propiciam significado aos educandos, pois estão vinculados a demandas sociais, culturais e econômicas de determinada localidade. Além disso, alguns documentos vêm problematizando e indicando perspectivas mais contextualizadas de ensino, como a Lei de Diretrizes e Bases da Educação Nacional (LDB) e as Diretrizes Curriculares Nacionais da Educação Básica (DCNs).

A LDB (Lei 9.394, 1996) garante, por meio dos artigos 35 e 36, à área das Ciências da Natureza e Suas Tecnologias, um currículo diversificado e articulado ao contexto. As DCNs (MEC, 2013) abordam a contextualização enquanto requisito curricular para propiciar a interlocução entre os diferentes campos do conhecimento. Em contrapartida, a Base Nacional Comum Curricular (MEC, 2017), apesar de destacar o termo contextualização, aposta em práticas contextualizadas limitantes, uma vez que a 
fundamentação de sua matriz teórica sustenta a aquisição de habilidades que garantem competências coerentes com uma lógica mercantil. Essa é uma discussão que não será aprofundada neste artigo, uma vez que se busca dialogar com aspectos relacionados à abordagem de temas, embora o trabalho com temáticas esteja relacionado a questões curriculares.

No entanto, cabe destacar que se defende aqui um pensamento curricular que adota a abordagem temática (Ferreira et al., 2019; Marques et al., 2020) e não a conceitual ${ }^{1}$, pois a utilização de questões do contexto não pode ser reduzida metodologicamente em um trabalhado a partir de conteúdos pré-estabelecidos. A percepção do contexto, a partir do referencial freireano, está relacionada à perspectiva de desvelamento e transformação da realidade, ultrapassando a ideia de inserir a temática em uma prática de ensino apenas como ilustração de conteúdos conceituais. Essa ideia de contextualização, segundo Ricardo (2010), é coerente com a perspectiva que toma a realidade como ponto de partida e chegada, visando sua problematização, em que se retorna à realidade com um novo olhar, para compreender e realizar ações. Nesse entendimento, a realidade vivida é descrita e interpretada pelos seus próprios sujeitos, e as compreensões sobre o contexto são aprofundadas com vistas à sua superação.

Essas ideias relacionam-se com o trabalho de Brick (2017) em seu estudo sobre a realidade. Assumimos a concepção de realidade reconhecendo-a como totalidade concreta, a qual considera fatos, relações, construções e processos enquanto características de um todo, que envolvem objetos do conhecimento dinâmicos, incompletos e inconclusos (Brick, 2017). Trata-se, portanto, de diferentes dimensões que devem ser analisadas, fomentando reflexões por meio de práticas educativas críticas de perspectiva freireana, direcionadas às vítimas dessa totalidade, enquanto sujeitos concretos e protagonistas da transformação das injustiças. Para Freire (2019), isso pode ser concebido pelo diálogo e problematização, que considera a realidade vivida como objeto de estudo, a qual se torna o foco das discussões, visando ao trabalho com temas de contradição social. A compreensão dessa realidade precisa fazer sentido e atingir todos os envolvidos (professores, estudantes e comunidade em geral), por isso, buscase, através dos temas, situações que, em alguma medida, os insiram nesse processo, ao mesmo tempo em que descrevam conflitos relacionados ao contexto.

A utilização de temáticas no Ensino de Ciências tem se mostrado uma possibilidade de discutir aspectos do entorno da escola, abordar temas significativos e ressignificar o estudo de conceitos científicos. Essa perspectiva se aproxima da abordagem dos temas de natureza contextual, como a de Paniz e Muenchen (2020), que valorizam o estudo da realidade e o diálogo sobre situações-problemas vivenciadas pela comunidade e ainda não percebidas por ela. Além disso, as referidas autoras apontam desvantagens na ideia de ciência pronta e imutável, sinalizando que vai contra o desenvolvimento dos conceitos científicos contextualizados. Halmenschlager e Delizoicov (2017) apontam que os temas de natureza contextual estão relacionados a fenômenos naturais ou tecnológicos, situações-problemas, questões ambientais e situações significativas da realidade, de modo geral.

1 Perspectiva de trabalho em que o currículo é estruturado a partir dos conceitos científicos. 
Essas situações significativas são denominadas, para o referencial freireano, situações-limite. São barreiras à compreensão crítica sobre a realidade, possíveis de serem problematizadas mediante o processo de conscientização que leva os sujeitos a se perceberem enquanto seres históricos e ativos em seus contextos (Freire, 2019). Nesse cenário de discussões sobre temas relacionados a contextos emergentes, que descrevem problemáticas locais, busca-se identificar e problematizar situações-limite na perspectiva do ensino e formação de professores de Ciências, sinalizando possibilidades de enfrentamento na prática pedagógica. Alguns estudos (Silva et al., 2016; Freitas \& Queirós, 2020a) versam sobre isso, do ponto de vista teórico-prático, apresentando experiências e proposições quanto à temática.

Silva et al. (2016) investigaram manifestações de professores da educação básica, pautando-se por adaptações da Investigação Temática (Freire, 2019), identificando situações-limite formativas e sinalizando como possibilidade de superação, a problematização das compreensões docentes sobre a realidade e a própria prática, visando ao desenvolvimento de outras atividades que contribuam com seus processos formativos. Freitas e Queirós (2020a) discutiram uma situação-limite apresentada no contexto da formação inicial, sobre concepções reproducionistas no processo de ensino e aprendizagem, indicando intervenções críticas como possibilidade de superação, pois o espaço escolar que deve considerar a cultura e os diferentes saberes dos sujeitos no movimento de participação pública.

Com isso, percebe-se a necessidade de dar visibilidade às situações-limite para além do campo teórico, vivenciando-as e refletindo sobre elas dentro e fora da sala de aula, encorajando os sujeitos a intervirem na sociedade enquanto cidadãos. Portanto, constata-se uma lacuna sobre as situações-limite, pois estas nem sempre são percebidas pelos docentes em seu fazer pedagógico e investigativo, mesmo permeando a cultura dos seres humanos e estando presentes nas interações em sala de aula ou nos contextos pesquisados. Dois movimentos podem ser pensados para diminuir essa lacuna, o primeiro caracterizado por um planejamento prévio, que garanta a identificação dessas situações em intervenções na sala de aula. O segundo, enquanto necessidade emergente de ressignificação de práticas já realizadas, pelo retorno ao que já foi desenvolvido, tendo por intenção problematizar e perceber aquelas ações por outras perspectivas, para assim, propor novas atitudes.

É importante salientar a pertinência dessas discussões no contexto do Ensino de Ciências e nos processos formativos de professores, já que o presente trabalho se caracteriza pelo segundo movimento descrito acima, pois realizou um aprofundamento teórico em resultados de três investigações que envolveram formação inicial de professores de Química, formação continuada de professores de Ciências e práticas no ensino de Química na educação básica (Fonseca, 2019; Tadeu, 2018; Maraschin, 2019). Além disso, também é possível afirmar que são feitas sinalizações teórico-práticas no sentido de contribuir para atividades de ensino vinculadas às realidades estudadas, permeadas por princípios do referencial freireano. Por fim, destaca-se que este trabalho busca apontar possibilidades de enfrentamento de situações-limite identificadas no contexto e na prática do Ensino de Ciências. 


\section{Problematização das situações-limite}

As situações-limite, para Freire (2019), são situações que estão imersas na historicidade dos homens e em suas aspirações, ou seja, situações nas quais os sujeitos encontram limites que impedem a percepção real dos fatos. É através das relações de homens e mulheres entre si e com o mundo que alguns obstáculos se apresentam e precisam ser superados, exigindo um nível maior de consciência para que sejam percebidos e avaliados. Segundo o autor, elas "[...] se apresentam aos homens como se fossem determinantes históricas, esmagadoras, em face das quais não lhes cabe outra alternativa, senão adaptar-se" (Freire, 2019, p. 130). São contradições sociais vivenciadas pelos sujeitos, vistas de maneira acrítica, por desconhecerem as causas dos problemas ou considerarem inviável a possibilidade de superação de determinada contradição. Quando as situações-limite são analisadas de modo acrítico, podem ser naturalizadas ou entendidas de forma limitada. Com isso, parece não haver formas de solução, e os sujeitos podem assumir uma postura de passividade diante das contradições sociais vivenciadas.

Freire (2019) trata desse conceito apresentando também a definição de atoslimite, que nada mais são que as ações voltadas à superação e/ou negação dos fatos. O patrono da educação brasileira traz, em suas reflexões, duas categorias muito importantes, que contribuem para que as situações-limite sejam transcendidas: o diálogo e a problematização.

O diálogo configura-se não pela relação "[...] de $A$ para $B$ ou de $A$ sobre $B$, mas de A com B, mediatizados pelo mundo" (Freire, 2019, p. 116). Enquanto isso, a problematização permite a pronúncia do mundo em um ato de (re)criação. No contexto educacional, o diálogo norteia a busca pelo conteúdo programático porque permite que educadores e educandos tenham autonomia para a escolha deste, mediante questões levantadas e discutidas sobre a realidade vivida. Nesse sentido, as situações-limite podem ser inseridas em um movimento de organização e sistematização de práticas de ensino que levem em conta as experiências dos sujeitos sem impor programas educacionais a serem seguidos.

Com relação à problematização no contexto educacional, sua relevância se encontra na capacidade de oferecer subsídios para que os educandos reflitam criticamente sobre a sua realidade, com o auxílio do conteúdo selecionado, voltando-se os olhares não apenas ao campo educacional, mas também histórico, econômico, social e político. Em outras palavras, problematizar as situações-limite permite que o povo as transcenda, percebendo seu papel no meio em que estão inseridos. Freire afirma que "[...] o que temos que fazer, na verdade, é propor ao povo, através de certas contradições básicas, sua situação existencial, concreta, presente, como problema que, por sua vez, o desafia e, assim, lhe exige resposta, não só no nível intelectual, mas no nível da ação" (Freire, 2019, p. 120).

Muenchen e Delizoicov (2013) apresentam, em seu marco teórico, a categoria problematização no contexto brasileiro, fundamentada em Freire, desde 1989, enquanto 
perspectiva curricular que vem mediando as práticas docentes de diversas iniciativas. Nascimento e Von Linsingen (2006) abordam a problematização das situaçõeslimite articuladas à Educação Ciência, Tecnologia e Sociedade (CTS), uma vez que a investigação de situações contraditórias pode ser entendida enquanto movimento de conscientização para estimular, nos estudantes, posicionamentos críticos diante de suas vivências.

A perspectiva de trabalho com temas CTS geralmente envolve a dimensão crítica da Ciência e Tecnologia; em especial, a aproximação Freire-CTS sinaliza para a problematização e superação de modelos e construções históricas sobre temas sociais. A abordagem de temáticas em uma perspectiva crítica contribui para desvelar pensamentos naturalizados sobre produtos que carregam conhecimentos de Ciência e Tecnologia e discutir, dentre outros aspectos, os processos de concepção e execução desses produtos (Auler, 2018), a exemplo das temáticas agrotóxico e leite, discutidas neste trabalho.

Alguns estudos na área da Educação em Ciências (Giacomini \& Muenchen, 2016; Almeida \& Gehlen, 2019) relacionam perspectivas freireanas com a Educação CTS no sentido de incentivar o protagonismo dos sujeitos não apenas no campo educacional, mas também enquanto facilitadora na reflexão, produção de questionamentos e compromisso social diante das problemáticas da sociedade. Nascimento e Von Linsingen (2006, p. 108) destacam que a proposta CTS se aproxima da percepção freireana, uma vez que também visa valorizar a realidade do educando, indicando que "[...] esse tipo de contextualização está praticamente assegurado na proposta de Freire: ao realizar o levantamento das situações-problema nas quais os educandos encontram-se imersos".

De forma sintetizada, a concepção de contextualização aqui adotada faz referência ao exercício de busca pelo rompimento de currículos lineares, organizados exclusivamente a partir de conteúdos conceituais. Porém, nas pesquisas em Ensino de Ciências sobre situações-limite na prática pedagógica de professores, há indicativos, segundo Silva et al. (2016), de que alguns professores de Ciências, quando se envolvem na organização de atividades didático-pedagógicas que influenciam a estruturação do currículo escolar, apresentam entendimento limitado em relação aos problemas sociais decorrentes da comunidade e a aspectos relacionados aos temas. Por isso, é necessário discutir as limitações apresentadas por professores em processos formativos, tanto em caráter continuado como em caráter inicial, sobre abordagem de temas, especificamente no que se refere às temáticas alinhadas aos princípios freireanos. Trabalhos como de Silva et al. (2016) e Rocha (2013) procuram analisar essas compreensões limitadas a partir das situações-limite.

Não obstante, as discussões aqui apresentadas estão balizadas no processo de codificação-problematização-descodificação (Freire, 2019), pois as três pesquisas (Fonseca, 2019; Tadeu, 2018; Maraschin, 2019), buscaram o desenvolvimento e a incorporação de novos conhecimentos sobre as temáticas pesquisadas a partir de conhecimentos anteriores. Essa tríade, na concepção freireana, parte exatamente desse movimento que tem por intenção compreender, de forma coletiva, a realidade vivida, 
a partir da investigação, descrição, reflexão de características histórico-culturais do contexto e sua interpretação, para assim atingir uma visão mais crítica e transformadora. Apesar de as pesquisas não terem sido desenvolvidas completamente por Investigação Temática, cabe destacar que a codificação-problematização-descodificação compõe essa perspectiva investigativa e balizou alguns dos processos das pesquisas, pois, ao se realizar o levantamento de informações, a reflexão, os primeiros diagnósticos e interpretações, considera-se que houve aproximação com as etapas de levantamento preliminar, codificação e diálogos descodificadores. Todas as etapas da Investigação Temática serão descritas no tópico "Abordagem de temas no Ensino de Ciências".

Delizoicov (1991) indica a problematização como elo da tríade, pois é a partir dela que as situações codificadas passam a ser compreendidas por novas perspectivas, emergindo a necessidade de aquisição de outros conhecimentos para enfrentar os problemas que se mostram. Portanto, essas discussões buscam apresentar de que forma três produções já finalizadas, uma em nível de graduação e duas em nível de mestrado (Fonseca, 2019; Tadeu, 2018; Maraschin, 2019), identificam e problematizam situaçõeslimite encontradas explícita ou implicitamente nos contextos pesquisados.

\section{Abordagem de temas no Ensino de Ciências}

No Ensino de Ciências, diferentes perspectivas marcaram as práticas escolares, focando no processo de profissionalização ou em uma formação cidadã. A possibilidade de articular conhecimentos da vida cotidiana e questões do contexto em atividades de ensino tem sido discutida como uma alternativa para superar o cenário escolar que separa o que é estudado daquilo que é vivenciado pelos sujeitos.

A organização desses processos a partir de temáticas, além de romper com a estrutura disciplinar, proporciona desenvolver propostas curriculares mais dinâmicas e coerentes com a realidade de cada contexto (Centa \& Muenchen, 2016). A Abordagem Temática no Ensino de Ciências vem sendo tratada por vários autores (Almeida \& Gehlen, 2019; Ferreira et al., 2019; Marques et al., 2020; Fonseca \& Lindemann, 2020) como possibilidade de orientação curricular. Nela, tem se levado em consideração as concepções freireanas de educação libertadora e os princípios da contextualização, que permitem inserir os educandos em seus processos de aprendizagem. A Abordagem Temática em Freire pauta-se na obtenção de Temas Geradores, que são selecionados e estruturam o programa curricular que é desenvolvido em aula, processo denominado Investigação Temática (Freire, 2019).

No que se refere à Investigação Temática, Delizoicov (1991) sistematizou esse processo para a educação formal em cinco etapas: levantamento preliminar; análise das situações e escolha das codificações; diálogos descodificadores; redução temática; e trabalho em sala de aula. Nessa sistematização, o levantamento preliminar corresponde à aproximação inicial à localidade estudada; a escolha das codificações volta-se para as contradições e situações que são vividas; os diálogos descodificadores retomam as contradições para obter Temas Geradores; a redução temática diz respeito ao estudo, 
por parte dos especialistas, sobre as descodificações e o planejamento dos conteúdos; e por fim, o trabalho em sala de aula acontece a partir do programa estabelecido.

Além disso, Delizoicov et al. (2011) propuseram uma dinâmica didáticopedagógica conhecida como Três Momentos Pedagógicos, a partir do trabalho com Temas Geradores na perspectiva freireana. Esse processo também tem sido utilizado para estruturar currículos (Araújo, 2015). O primeiro momento, Problematização Inicial (PI), busca conhecer a compreensão dos estudantes em relação à situação abordada e, segundo Araújo (2015) e Centa e Muenchen (2016), está relacionado ao processo de Investigação Temática pelas três primeiras etapas (levantamento preliminar, codificação e círculo de investigação temática), baseando-se no diálogo para obter informações. Já o segundo, Organização do Conhecimento (OC), tem como intenção o estudo de conhecimentos sistematizados, os quais são abordados para uma melhor compreensão dos temas e da PI, e, segundo Centa e Muenchen (2016), corresponde à quarta etapa da Investigação Temática, denominada redução temática, pois, baseandose nos dados obtidos anteriormente, formam-se questões geradoras que determinarão o planejamento das aulas e os conteúdos a serem ensinados. O terceiro, Aplicação do Conhecimento (AC), ocorre quando o aluno, após apreender o conhecimento, utiliza-o para compreender outras situações que tenham relação com a inicial, e, segundo Centa e Muenchen (2016), aproxima-se da quinta etapa da Investigação Temática, uma vez que acontece o trabalho em sala de aula.

Ratificamos que a dinâmica dos Três Momentos Pedagógicos surge, e, portanto, deve estar alinhada aos pensamentos freireanos. Assim sendo, deve pautar-se no desenvolvimento curricular diante do diagnóstico do cotidiano dos educandos, sendo necessários planejamento e ação docente, perpassando questões metodológicas, contribuindo para uma reestruturação curricular em que a prática pedagógica é norteada pelos temas e o ponto de partida das atividades é a compreensão dos discentes sobre a realidade. Do contrário, mostrar-se-ão apenas perspectivas metodológicas dissociadas dos princípios freireanos, correspondendo a práticas conteudistas, estáticas e mecânicas. Muenchen e Delizoicov (2014) sinalizam que quando os Três Momentos Pedagógicos são vistos apenas como metodologia, o primeiro momento, de PI, acaba por não estabelecer critérios para a seleção de situações significativas e contraditórias do contexto, reduzindo-se a um mero pretexto para introduzir, no segundo momento, de OC, conteúdos abordados tradicionalmente.

Traçadas essas considerações, é inerente que a Investigação Temática e os Três Momentos Pedagógicos, propostos para o Ensino de Ciências, têm como gênese a perspectiva freireana, principalmente no que se refere às categorias de problematização e dialogicidade enquanto princípios balizadores, presentes em ambas as propostas, haja vista que tanto a Investigação Temática, quanto os Três Momentos pedagógicos, precisam considerar as relações existentes entre os seres humanos e o mundo, incluindo as trocas culturais e de saberes que se estabelecem, abrindo possibilidades para a ressignificação das primeiras visões mágicas em visões críticas (Freire, 2019). Halmenschlager (2011) 
destaca as possibilidades de diálogo criadas a partir da realidade, sendo a aprendizagem em Ciências desenvolvida pelo senso crítico e conscientização de todos. Nesse mesmo estudo, a autora realiza um levantamento de propostas de Abordagem Temática, que são desenvolvidas no Ensino de Ciências, encontrando algumas possibilidades: Abordagem Temática em Freire; Currículos CTS; Abordagem Temática em Freire relacionada ao enfoque CTS; e Situação de Estudo. A seguir, essas possibilidades serão brevemente descritas, conforme Halmenschlager (2011).

A Abordagem Temática em Freire encontra-se situada na proposta de educação libertadora, em que os conceitos científicos são selecionados junto à comunidade, diante da identificação de situações contraditórias que evidenciam situações-limite. Logo, o currículo é organizado a partir de Temas Geradores obtidos pela Investigação Temática. Os Currículos CTS buscam considerar o contexto dos alunos para debater questões voltadas à Ciência e Tecnologia, construindo currículos que se encontram situados no campo das Ciências Naturais e das Ciências Sociais. Com isso, apesar da escolha do tema não ter a necessidade de estar vinculada a um processo de investigação, a organização curricular deve contemplar aspectos científicos, tecnológicos, históricos, éticos, sociais e econômicos. A Abordagem Temática em Freire, relacionada ao Enfoque CTS, configura-se como uma possibilidade de articulação curricular que trabalha com temas de relevância social, que permitem discussões sobre Ciência e Tecnologia para viabilizar a leitura do mundo contemporâneo. Aspectos sobre essa articulação foram discutidos no item anterior. Por fim, a Situação de Estudo propõe a reorganização curricular, priorizando a contextualização e interdisciplinaridade dos conteúdos de Ciências, em que a seleção e organização dos conceitos estão relacionados a uma situação real presente no contexto dos estudantes, devendo ser, sobretudo, problematizada junto a eles.

Com isso, é possível compreender múltiplas faces e intenções do trabalho com temas no Ensino de Ciências. Cabe destacar que essa abordagem pode atingir diversas dimensões, desde a motivação até o desenvolvimento mais crítico de compreensão da realidade, sendo essa última mais próxima das discussões freireanas. Para Freire (2019), os temas trazem consigo situações contraditórias que envolvem uma determinada comunidade e seus indivíduos. Tais situações limitam a possibilidade de os sujeitos perceberem o "inédito-viável", ou seja, de perceberem que um outro mundo é possível, portanto, viável, e inédito por conta de não ter sido ainda percebido. O que se discute no presente trabalho aproxima-se da abordagem de temas que segue a perspectiva freireana, visto que "[...] os temas representam situações-limites da comunidade escolar e os conteúdos programáticos visam auxiliar o aluno a compreender e superar a situação abordada" (Halmenschlager, 2011, p. 19). Um aspecto importante de destacar sobre a natureza dos temas em Freire diz respeito à necessidade de identificação de situações-limite para obtenção de temáticas significativas do contexto e sua consequente problematização.

Dessa forma, a escolha de temas e conteúdos é orientada pelo contexto do educando, que não é vazio de conhecimento. Schneider et al. (2018) ratificam a 
importância deste para a organização de um currículo pautado pela Abordagem Temática, justificando que se deve buscar romper com perspectivas tradicionais de ensino que trazem a ideia de conceito científico com fim em si próprio. O currículo na dimensão da Abordagem Temática em Freire utiliza-se de conceitos científicos como um meio para compreender os temas que emergem do diálogo e problematização. Essa dimensão tem sido abordada em trabalhos na Educação em Ciências. Destacam-se três trabalhos que discutem relações teóricas ou propostas de intervenção curricular por abordagem de temas, na perspectiva CTS-Freire.

Nascimento e Von Linsingen (2006) refletem sobre a necessidade de romper com um currículo que não contempla situações cotidianas dos educandos, sinalizando que os cursos de formação de professores precisam formar professores com concepções da educação progressiva e "[...] que integrem os diversos conhecimentos de modo que esses educadores consigam realizar um trabalho interdisciplinar nas escolas onde atuarão futuramente" (Nascimento \& Von Linsingen, 2006, p. 110). O trabalho de Muenchen e Auler (2006) versa sobre o contexto da educação básica, no entanto, traz apontamentos sobre as dificuldades dos professores para compreender o trabalho com temas enquanto reorganização curricular e não como uma simples metodologia que se utiliza de um tema escolhido a partir de conteúdos, na tentativa de realizar uma prática contextualizada. Como alternativa para superar tais situações, iniciam-se diálogos sobre o papel das universidades, que devem trabalhar essas concepções na formação inicial, rompendo com a linearidade de currículo e conteúdos.

O último estudo, de Freitas e Queirós (2020b), analisa um processo de Investigação Temática no contexto do ensino superior, discutindo inquietações existentes na formação docente quanto às atividades nas escolas, como, por exemplo, o pouco tempo para desenvolver trabalhos fora da ementa a ser cumprida, além da falta de criticidade dos próprios licenciandos, fator limitante que não tem sido contemplado pelos cursos de graduação. Além disso, também há indicativos de que os processos formativos de professores envolvendo a perspectiva freireana (Bomfim, 2018), especialmente a Investigação Temática, contribuem para superar barreiras apresentadas pelos docentes no que se refere à questão pedagógica e curricular. A abordagem da perspectiva temática, de modo geral, influencia e auxilia a problematizar aspectos considerados imutáveis nos espaços escolares, abrindo espaço para articular outras dinâmicas, a exemplo do trabalho coletivo, a organização e desenvolvimento de práticas educativas que tenham como ponto de partida o contexto local e a mudança na abordagem de ensino, e, portanto, na concepção de currículo.

\section{Percurso metodológico}

Tendo em vista o trabalho com temas como possibilidade de superação de práticas pedagógicas exclusivamente conceituais e a articulação de processos de ensino de dimensão contextualizada, esse artigo retomou pesquisas realizadas em contextos e tempos distintos balizadas pelo referencial freireano. Para identificação 
de convergências, realizou-se a releitura de três trabalhos desenvolvidos pelos autores, sendo duas dissertações (Fonseca, 2019; Tadeu, 2018) e um trabalho de conclusão de curso (Maraschin, 2019). Foram encontrados, em comum, a Abordagem Temática e o Estudo da Realidade. Por isso, caracteriza-se como uma pesquisa qualitativa, objetivando interpretar um objeto de estudo a partir de experiências dos sujeitos, os quais lhes atribuem significados (Denzin \& Lincoln, 2006; Stake, 2011). Nesse primeiro olhar, foi possível perceber indicativos de situações-limite em todos os estudos. Após, retornou-se aos trabalhos, buscando selecionar as situações-limite a serem apresentadas e problematizadas.

Os três trabalhos discutiram, em diferentes medidas e enfoques, aspectos relacionados ao trabalho com temas, possibilidades de reorganização curricular e redirecionamento da prática pedagógica. Essas discussões estiveram colocadas em torno da formação de professores, tanto em caráter continuado quanto em caráter inicial, bem como práticas no Ensino de Ciências. No entanto, neste artigo, busca-se apresentar e discutir possibilidades de articular uma prática contextualizada a partir das situações-limite identificadas em cada trabalho. Cabe destacar que o foco dos três trabalhos, no contexto em que foram desenvolvidos, não se ateve a identificar e discutir situações-limite, mas essa necessidade surgiu dos autores para avançar na compreensão das situações-limite, mostrando que elas estiveram presentes nos trabalhos realizados. A partir disso, buscou-se apresentar problematizações acerca das situações-limite identificadas nas três produções, num movimento de busca de superação. Diante disso, passa-se a apresentá-las brevemente.

Um dos trabalhos (Fonseca, 2019) buscou identificar e compreender as potencialidades e limitações na abordagem de temas a partir da compreensão de professores de Ciências de uma rede de ensino municipal sobre a temática agrotóxico. O contexto da pesquisa, bem como da atuação dos professores, possui um cenário com características agrárias, pois o município em que tais docentes atuam possui as atividades econômicas pautadas pela agricultura, por isso, o tema agrotóxico é pertinente para esse contexto. Além disso, têm sido constatadas intoxicações de moradores por esses produtos em localidades próximas às áreas de cultivo. Essa temática foi elencada a priori pelas características da realidade: saúde coletiva, questões socioambientais e socioeconômicas. O processo de investigação temática não foi realizado para obtenção do tema, visto que é necessário um coletivo de professores engajados em um objeto de estudo a fim de qualificar a prática pedagógica, ou seja, precisa uma equipe docente em constante estudo buscando situações que sejam significativas para uma realidade. Também se faz necessário um esforço enquanto organização curricular e carga horária para planejamento. Esses aspectos não puderam ser contemplados, contudo, não deslegitimam a proposta com o tema agrotóxico como uma abordagem relevante do contexto. A realização de um processo de obtenção da temática poderia revelar valores e conteúdos próximos aos trabalhados com o agrotóxico. É possível afirmar que o trabalho realizado com o tema agrotóxico está próximo das discussões na Educação 
CTS, mas que se atribuem princípios da pedagogia freireana para discutir a temática, como a problematização e a dialogicidade.

Os sujeitos participantes da pesquisa foram 11 dos 12 professores de uma rede municipal de ensino, que responderam aos instrumentos de obtenção de dados: questionário e entrevista semiestruturada. Esses instrumentos foram aplicados no intuito de perceber a compreensão dos professores em relação ao trabalho com temas, a fim de identificar obstáculos e potencialidades, bem como perceber suas intenções na abordagem da temática agrotóxico. As considerações acerca desse trabalho são apresentadas no item "Problematizando a cultura do silêncio das práticas pedagógicas", em que se identificam situações-limite na prática pedagógica das professoras e sinalizamse possibilidades de superação.

O segundo trabalho analisado neste artigo (Tadeu, 2018), buscou compreender aspectos que evidenciassem a sensibilização do olhar de 12 estagiários, em um curso de Química Licenciatura, para questões que transcendessem o conteúdo conceitual por meio de um processo formativo balizado pela dialogicidade e problematização, articulando teoria e prática. A escolha pelo componente de Estágio Supervisionado I deu-se pela compreensão do que significa essa etapa na formação. De acordo com a ementa curricular do curso em que a pesquisa foi desenvolvida, espera-se que, nesse momento, os estagiários identifiquem, analisem e interpretem as formas de atuação do professor, bem como realizem observações reflexivas sobre a prática pedagógica, estruturas curriculares e planejamento do ensino de Química para o Ensino Médio. Tem como alguns de seus objetivos: leituras e discussões de referenciais teóricos, reflexões críticas sobre realidades dos contextos escolares vivenciados, elaboração de planos de aulas, bem como elaboração e execução de uma atividade em sala de aula, em parceria com o professor regente. Cabe ressaltar que o estágio não se dedica apenas à parte prática, o fazer com o fim em si mesmo, mas sim, ao saber fazer. Nessa perspectiva, o saber fazer está diretamente relacionado à sustentação teórica que guiará o planejamento de aulas e atividades que serão desenvolvidas durante essa etapa da formação.

Para tanto, esse espaço formativo é caracterizado por constantes diálogos e reflexões acerca das observações que os estagiários vivenciam no contexto escolar. Considerando tais objetivos, entendeu-se ser relevante aprofundar os estudos acerca dos princípios freireanos, proporcionando uma forma de pensar, estudar e praticar o planejamento de ensino por meio de uma adaptação da Investigação Temática. Essa escolha se deu por considerar-se importante a categoria freireana da práxis, teoria articulada à prática. Durante a formação inicial, especificamente nos estágios, a práxis é relevante porque, muitas vezes, os licenciandos agregam uma expectativa na prática, minimizando involuntariamente a teoria que sustenta tal possibilidade. $\mathrm{O}$ desenvolvimento do trabalho foi justificado pelo fato de, mesmo com diversas recomendações presentes nos documentos oficiais sobre a relevância de um ensino crítico, que contribua com a formação cidadã do estudante, ainda se observam marcas muito fortes da concepção tradicional de ensino-aprendizagem no cenário educacional. 
O processo formativo ocorreu em dez encontros e foi analisado à luz da Pesquisa Narrativa de Connelly e Clandinin (1995), olhando para produções de narrativas do vivido, escritas pela pesquisadora, referente a momentos marcantes no decorrer dos encontros. Estas foram guiadas, buscando subsídios para responder a uma interrogação fenomenológica que caracterizou as categorias de análise da pesquisa (Bicudo, 2011). As observações referentes a esse trabalho apresentam-se no item "Problematizando compreensões de planejamentos de aulas na Formação Inicial", no qual é apresentada a situação-limite de dimensão pedagógica observada e os caminhos pelos quais buscou sua superação.

O último trabalho (Maraschin, 2019) teve como objetivo encontrar algumas possibilidades que o tema leite e seu beneficiamento podem apresentar para práticas pedagógicas do ensino de Química na educação básica, considerando o contexto de uma escola localizada em um município que faz fronteira com o Uruguai, uma turma de terceiro ano do ensino médio e estudantes da zona rural, em maior parte descendentes de povos imigrantes que trabalham com a produção leiteira. A escolha do tema leite foi realizada a partir da aproximação com as três primeiras etapas da Investigação Temática.

O levantamento preliminar não foi realizado por uma equipe interdisciplinar, apenas pelo pesquisador, no entanto, buscou-se por diferentes elementos que compunham o contexto pesquisado, por exemplo: levantamento de dados a respeito da economia do município no site do Instituto Brasileiro de Geografia e Estatística, que indicou a localização de uma importante bacia leiteira naquela região e a quinta posição no ranking Estadual de municípios sobre a produção de leite, no ano anterior; levantamento sobre os núcleos familiares dos estudantes da turma, por meio de conversa com a comunidade escolar (professores, alunos etc.), reconhecendo algumas influências culturais daquele espaço, uma vez que aproximadamente $65 \%$ desses núcleos residem no campo e têm na produção leiteira sua forma de sustento; e análise das rotinas da vida no campo, junto a narrativas enviadas via aplicativo WhatsApp.

A análise das situações e a escolha das codificações foram realizadas em dois momentos, sendo o primeiro denominado pré-intervenção (de responsabilidade apenas do pesquisador, com base no levantamento realizado), e o segundo momento denominado intervenção (na intenção de legitimar ou corrigir os diagnósticos feitos na pré-intervenção). A temática leite foi comum aos dois momentos, sendo incorporados a ela diálogos sobre sua importância para as famílias, para a economia do município, cuidados necessários para a produção, possibilidades de aplicação do produto pósordenha, dentre outras, todos registrados em gravações de áudio das aulas e transcritos. Nos diálogos descodificadores, realizados também no momento da intervenção, por docente e discentes, buscou-se problematizar cada diálogo tido com os educandos, focalizando nos aspectos levantados sobre a temática leite, na tentativa de perceber questões ainda não vislumbradas a partir da reflexão sobre as práticas descritas e suas implicações histórico-culturais, sociais e éticas. 
Cabe registrar que essa intervenção de ensino, organizada a partir do diálogo e da problematização da realidade local, foi dividida em três encontros de duas horas/ aula cada. Os dados obtidos das narrativas dos discentes sobre a rotina de trabalho no campo, das transcrições das gravações dos diálogos tidos em sala de aula sobre o tema e suas relações com o componente curricular de Química, e, por fim, da avaliação final da intervenção que correspondia à entrega de pesquisa escrita e apresentação oral de seminários sobre o beneficiamento do leite, foram analisados qualitativamente. Portanto, buscou-se evidenciar a articulação entre os aspectos teórico-conceituais e a cultura local dos estudantes, visando torná-los protagonistas do seu processo de ensino e aprendizagem. As reflexões sobre esse estudo encontram-se no item "A escolha de temas na educação básica orientada pelo contexto", no qual se identificou a situação-limite na compreensão limitada que aqueles estudantes tinham sobre sua realidade, podendo ser superada a partir do trabalho com temas.

\section{Resultados e discussões}

Conforme dito anteriormente, a situação-limite foi a categoria freireana elencada, por estar presente nos três estudos. Portanto, atentou-se para a presença em comum desta em todas as pesquisas e para o desejo de melhor compreendê-la, ao invés de relacionar os conteúdos dos textos em si. As situações-limite identificadas em cada estudo indicam aspectos na prática pedagógica e no ensino, que necessitam ser superados. Em alguns momentos, uma mesma situação parece mostrar-se em mais de um trabalho, em razão de duas pesquisas versarem sobre a formação de professores. No entanto, são abordagens distintas, mas que possuem a mesma matriz teórica e compartilham do mesmo princípio pedagógico de trabalhar, em alguma medida, questões do contexto e abordagem de temas. A partir das situações identificadas em cada trabalho, apresentam-se a seguir, discussões que envolvem as análises das falas dos sujeitos participantes das pesquisas, com o intuito de apontar possíveis formas de superar os cenários limítrofes em relação à realidade e ao contexto de trabalho.

\section{Problematizando a cultura do silêncio das práticas pedagógicas}

A partir do estudo de Fonseca (2019), foi possível perceber que não havia clareza na distinção entre conteúdo e tema, tendo a necessidade de cumprir sistematicamente o programa curricular. Com isso, questões do contexto eram abordadas para trabalhar conteúdos conceituais ainda que houvesse uma abertura para inserir aspectos da realidade e o interesse dos estudantes nas discussões em sala de aula. Como encaminhamento final, sistematizou-se uma proposta de ensino na forma de ensaio teórico-prático (Fonseca \& Lindemann, 2020) como sugestão à abordagem de uma temática pertinente ao contexto vivenciado pelos professores, assim como à sua realidade de trabalho. Desse modo, foi possível perceber que a prática pedagógica das professoras era guiada de acordo com o currículo escolar tradicional (Fonseca, 2019), no entanto, as questões relacionadas ao contexto pareciam ser abordadas em aula, mesmo que em momentos pontuais, para 
trabalhar conteúdos conceituais, conforme demonstram os fragmentos das falas a seguir. Cada professora foi identificada por uma letra seguida de um numeral.

[...] eu até reconheço como professora a gente erra por que fica preso naquele conteúdo ali só, e quer correr contra o tempo e uns [alunos] têm as dificuldades e a gente acaba deixando de trabalhar, poderia incluir, acrescentar, melhorar até as aulas, e a gente acaba correndo naquele ali, no resumo do conteúdo e deixa as vezes a desejar mesmo nessas questões [do contexto] que são importantes pra eles. Criticar, debater, argumentar, se posicionar é interessante (P10) (Fonseca, 2019, p. 62).

[...] eu acho que ele teria que ser um trabalho assim paralelo entendeu, que tu tem que ver a listagem de conteúdos, elas te exigem isso. É, entendeu, o projeto ele pode contemplar de $6^{\circ}$ a $9^{\circ}$ ano, desde que tu intercale com teu conteúdo, tu tem um conteúdo para vencer, eu tenho que dá, vamos dizer células, eu tenho que dá agora sistema cardíaco. É, claro que eu posso entra com o agrotóxico, [...] só que tem os projetos que elas já te exigem, sexualidade, drogas, tem trânsito, meio ambiente, tu entendeu, já tem vários projetos, então ele tem que entrar que eu possa abordar ele no máximo uma vez por semana, tu entendeu? (P2) (Fonseca, 2019, p. 52).

Nota-se que os conteúdos conceituais são o foco dos estudos no trabalho desenvolvido pelas professoras. P10 reconhece que se detém muito aos conceitos e poderia incluir outras discussões para contribuir com a formação dos estudantes. Para P2, a abordagem dos conteúdos conceituais merece atenção exclusiva a partir da listagem de conceitos pré-estabelecidos pela escola. A professora considera que o tema agrotóxico pode ser trabalhado, mas de forma paralela aos conteúdos conceituais tradicionalmente abordados. Com isso, percebe apenas uma maneira de trabalhar os conteúdos, desconsiderando a possibilidade de abordá-los a partir da temática agrotóxico, mencionando que deve ser visto em um projeto paralelo. Percebe-se uma visão limitada em relação à organização do currículo, na qual a listagem de conteúdos conceituais direciona o que deve ser trabalhado.

O tema, portanto, é visto a partir da perspectiva conceitual, em que os conteúdos direcionam grande parte das atividades de ensino, e a temática é abordada em segundo plano ou, muitas vezes, como exemplo pontual, em algum aspecto do conteúdo proposto. Essa concepção de que contextualizar um tema/conteúdo consiste em exemplificações do cotidiano reduz a potencialidade do trabalho com temáticas que poderiam demonstrar aspectos significativos do contexto, e esse acaba tornando-se apenas uma motivação aos conteúdos tradicionalmente trabalhados. O cotidiano, segundo Roso et al. (2015), poderia ser visto como um local de manifestação de contradições sociais mais amplas, em que se identificam problemas/temas, passando-se a questionar a complexidade presente no contexto. 
A escolha sobre o que é abordado e como é trabalhado em aula é do professor, no entanto, Becker (1995) aponta que o modo de pensar o conhecimento influencia o modo como o docente realiza sua prática, ou seja, o trabalho realizado pelo professor é influenciado de acordo com sua visão em relação aos conteúdos e o que acredita ser mais pertinente. Do mesmo modo, segundo Tardif (2000), boa parte dos professores tem alguma influência de sua história de vida e escolar em sua prática.

É possível identificar algumas dimensões distintas a partir da exposição das professoras, porém, complementares entre si, que são caracterizadas como situaçõeslimite relacionadas ao trabalho das docentes e à própria visão de mundo, que estão próximas das categorias analíticas identificadas no estudo de Silva et al. (2016). Os autores, ao analisarem situações-limite de professores de Ciências no contexto de obtenção de Temas Geradores, durante um processo formativo, perceberam limites a serem superados: situações-limite numa dimensão pedagógica e situações-limite acerca da percepção da realidade.

Numa dimensão pedagógica, as situações-limite são barreiras na compreensão dos professores, que impedem a articulação de um currículo crítico de Ciências, já que um entendimento limitado sobre a organização curricular pode influenciar o trabalho pedagógico dos docentes. Em certa medida, as professoras entendem que as atividades que desenvolvem precisam ser norteadas exclusivamente pela listagem de conteúdos conceituais que tradicionalmente é trabalhada. Com isso, parece não haver espaço para inserção de questões locais ou problemáticas ligadas ao contexto. Isso legitima uma compreensão limítrofe sobre o desenvolvimento das atividades didático-pedagógicas dos professores.

Já as situações-limite acerca da percepção da realidade estão relacionadas às visões limitadas que os professores possuem sobre a realidade, que, com isso, compreendem determinados problemas e contradições sociais de forma acrítica e superficial. A fala de P2 expressa essa visão em relação à abordagem do tema agrotóxico, embora reconheça a pertinência de trabalhar tal temática:

É importante [trabalhar o tema agrotóxico] e acho que até falho assim que deveria trabalhar mais assim aprofundado e eles têm essa vivência né! Faz parte da realidade deles, a nossa escola mesmo mais ainda, então até eles podem contribuir, contribuem com informações, tem mais até que ensinar a gente do que até a gente, com a troca, até poderia explorar mais. [...] Porque é interessante em todos [os anos] eu acho, só adequando ao nível, e é uma informação até pra gente trabalhar mais é interessante que fosse em todos eu acho, $6^{\circ}$ ano, $8^{\circ}$ ano (P10) (Fonseca, 2019, p. 61).

A professora reconhece a relevância de trabalhar a temática agrotóxico para o contexto vivenciado pelos estudantes. Pode-se dizer que possui uma visão, em certa medida, crítica em relação à abordagem do contexto em sua prática pedagógica, entretanto, não demonstra indícios da articulação desse trabalho. Assim como no estudo de Coelho (2005), a professora parece identificar o problema, mas não mostra 
uma visão crítica sobre sua causa, talvez por estar nele inserida. O estudo da autora tratava sobre professores de Química no contexto de mineração em Criciúma/SC, em que reconheciam trabalhar temas com aspectos sociais. De forma análoga, P10 percebe o tema como importante para a realidade, contudo, não relaciona com questões locais, como a contaminação aérea ou a produção de alimentos. Discussões sobre situaçõeslimite de professores têm sido foco de alguns estudos, a exemplo de Rocha (2013) e Silva et al. (2016), e alguns indicativos apontam que há relações com os processos formativos dos professores, pois as situações-limite podem indicar a compreensão sobre a realidade, bem como lacunas na formação docente em relação a um ensino contextualizado.

A concepção limitada de currículo é uma situação-limite que se materializa no reducionismo da prática docente em apenas executar um currículo pensado por especialistas, sem considerar a autoria do professor sobre o seu próprio trabalho pedagógico. Nessa discussão, também está relacionada uma limitação na concepção de currículo, que, em muitos espaços escolares, é entendido como uma simples listagem de conteúdos conceituais. Estudos como o de Bomfim (2018) indicam que a superação desse cenário pode dar-se a partir de atividades que envolvem a perspectiva freireana, em especial o processo de Investigação Temática. A autora identificou que, após alguns professores de Ciências apresentarem o medo como um obstáculo na estruturação curricular, organizou-se um processo formativo, constatando a superação dessa barreira via pedagogia de Freire. Por isso, entende-se que as discussões sobre a abordagem de temas enquanto estruturação curricular podem fazer parte de formações envolvendo as professoras, oportunidade ainda não realizada.

Pode-se dizer que as professoras, mesmo reconhecendo ser pertinente um trabalho mais aprofundado sobre um tema, mantêm uma postura que contribui para uma cultura do silêncio ${ }^{2}$ (Freire, 2019), pois se mantêm em silêncio, mesmo sem a consciência disso, adaptando-se à realidade e desenvolvendo um trabalho que contribui para a conservação de um cenário que não problematiza as contradições sociais. Isso constitui uma situação-limite, pois há o reconhecimento sobre um tema relevante ao contexto e à prática de ensino.

No entanto, apesar de a temática agrotóxico ser identificada pelas professoras como pertinente de ser trabalhada para o contexto, não é vista por essas como uma contradição social. Estamos diante de uma situação-limite freireana, que precisa ser problematizada em contextos formativos. Por isso, é relevante abordar temas que carregam contradições sociais em processos formativos. Na tentativa de incluir tais temas em processos de ensino, aponta-se para discussões entre professores, como grupos de estudo e leitura sobre o processo de estruturação curricular, constituindo coletivos de formação. Também cabe salientar a importância da formação para a equipe gestora, coordenadores e supervisores pedagógicos no sentido de os professores não se sentirem isolados e sem um apoio enquanto planejamento e reflexão da prática pedagógica.

2 Caracteriza-se como uma condição em que os sujeitos oprimidos se sentem emudecidos, sem ter a sua voz ouvida, sendo excluídos de decisões sobre suas próprias vidas. 
Além disso, é importante considerar que essas mudanças e propostas curriculares constituem-se enquanto processo e são construídas ao longo do tempo, portanto, é um desafio permanente articular processos educativos efetivamente comprometidos com problemáticas do contexto, visando à sua transformação. Experiências como a da rede municipal de educação de Chapecó (1997-2004) (Possamai, 2018), que implementou uma política de estruturação curricular fundamentada no pensamento de Freire, demonstram que os professores envolvidos consideraram difícil trabalhar com essa perspectiva, pois estavam acostumados com outra dinâmica de trabalho. Porém, anunciar propostas nesse formato faz-se necessário no sentido de distanciar-se da cultura do silêncio que acaba aprisionando a autonomia do fazer pedagógico.

A conservação dessa cultura pode estar relacionada a vários aspectos, como a própria cultura escolar viciada na demanda conceitual, a carga horária extensa de trabalho e o reducionismo da prática docente. Esses fatores por si só já indicam barreiras que precisam ser superadas no sentido de possibilitar melhores condições de trabalho pedagógico. Além disso, o medo pode impedir os professores de efetivarem práticas comprometidas com um ensino que dialoga com a realidade. Para Alves e Silva (2015), esse medo impede os professores de assumirem sua liberdade devido à ausência de autonomia e autenticidade. Com isso, sentem-se seguros ao renunciar sua responsabilidade, mantendo os processos educativos que já estão acostumados e aceitando a imposição de outras instâncias, seja enquanto gestão, seja em relação ao próprio currículo elaborado em contexto distante da prática vivenciada. Como já mencionado, estudos têm apontado que a superação desse medo pode ocorrer a partir de atividades com a perspectiva freireana.

Por outro lado, podem sentir-se seguros realizando atividades com outros colegas, por exemplo. O trabalho coletivo pode auxiliar na superação de práticas de ensino reducionistas e na articulação de um trabalho que dialoga com o contexto. Isso indica que o desenvolvimento de atividades didático-pedagógicas no coletivo contribui para superação, em um primeiro momento, desta barreira que é a insegurança de fazer algo diferente por receio de arriscar ao novo, pois pensar coletivos de formação pode favorecer novos modos de planejamento e desenvolvimento do ensino, sendo, ao mesmo tempo, um momento de formação para os envolvidos. De forma geral, os processos formativos de professores parecem ser uma alternativa na superação de situações que impedem os docentes de desenvolverem práticas educativas que abordem aspectos da realidade. Proposições nessa perspectiva foram sinalizadas em trabalho anterior (Fonseca \& Lindemann, 2020). Nesse sentido, a aposta na formação de professores no contexto da educação básica pode favorecer a compreensão crítica da realidade e a reflexão sobre o próprio trabalho pedagógico. 


\section{Problematizando compreensões de planejamento de aulas na Formação Inicial}

Ao olhar para o trabalho desenvolvido por Tadeu (2018), que realizou um processo formativo com estagiários de Licenciatura em Química, balizados pelos princípios freireanos, e teve sua sistematização aproximando-se das etapas da Investigação Temática (Freire, 2019), pode-se perceber que a abordagem mais crítica desenvolvida durante os encontros propiciou a problematização de uma visão difundida na formação acadêmica, que se embasa na repetição sucessiva de atividades como forma de aprender a fazer melhor. Ainda, demonstrou a influência da concepção propedêutica de ensino e aprendizagem, evidenciada pela compreensão de que um estágio serve necessariamente como preparação para o próximo. Observou-se que essas visões de aprendizagem se mesclam, muitas vezes, com uma visão de formação que merece ser dialogada e problematizada. Nesse sentido, a narrativa a seguir explicita uma vivência que possibilitou tais percepções. Cada licenciando, assim como a formadora, foi identificado por uma letra seguida de um numeral.

[...] - O que vocês estão achando das nossas aulas? Gostaram do Estudo da Realidade realizado semana passada? (F1).

Nesse momento um silêncio toma conta da sala, rostos fechados, e um clima de tensão se instaura. O silêncio é quebrado quando um aluno se manifesta, e depois outro, e mais outro...

- Eu não estou entendendo essas aulas, não vou sair daqui preparado para o próximo estágio! O Estudo da Realidade foi bem legal, gostei de estar na escola e conversar com as pessoas, mas isso não vai me ajudar a ser professora no próximo semestre no estágio 2 (L1).

— Eu achei que iria planejar aulas todas as semanas, e aprender a fazer isso bem. (L2).

- Eu pesquisei no PPC e vi que realmente tem uma saída de campo que entendi que foi essa que nós fizemos, e vi que as aulas estão sendo realizadas de acordo com esse documento, mas será que isso vai bastar para o próximo estágio? (L3).

- As outras turmas dos semestres passados não tiveram isso, porque estamos diferentes? [...] (L4) (Tadeu, 2018, p. 67).

As falas dos licenciandos explicitam uma situação-limite de dimensão pedagógica, pois demonstraram estar desejosos em aprender sobre planejamento de aulas e em saber como estruturar um plano de aula, mas se limitaram a uma concepção de formação propedêutica, na qual ocorre apenas a aplicação de uma listagem de conteúdos disponibilizada pela professora regente da turma. Essa situação-limite também está próxima do que Carvalho (2012) denomina de visão simplista, ou seja, 
uma visão de aprendizagem que os estagiários já trazem em sua bagagem cultural e, de certa forma, faz-se presente na formação inicial, marcada pela influência da concepção de ensino tradicional/propedêutico que balizou a escolarização da maioria, senão da totalidade dos licenciandos. Isso também indica, em certa medida, uma lacuna no processo de formação inicial dos licenciandos, já que a articulação de práticas escolares contextualizadas com olhar voltado à realidade da comunidade escolar poderia ter mais espaço na licenciatura, na disciplina de estágio e em outros componentes curriculares.

Observou-se uma compreensão da prática desvinculada da teoria, com fim nela mesma, como discutido anteriormente. Assim, a categoria práxis em Freire teve uma grande relevância para problematização dessa concepção, pois possibilitou a construção do conhecimento sobre o estágio como um lócus de discussão e reflexão da prática docente e dos contextos escolares, bem como um espaço de planejamento de aulas articulados constantemente à teoria. Cabe enfatizar a importância que possui conhecer e investigar a comunidade escolar para se pensar o currículo, e, consequentemente, o planejamento de aulas, tanto em processos formativos iniciais como continuados, haja vista que, por meio de ações, como o Estudo da Realidade, ficam evidentes limitações, contradições sociais e características que estão de plano de fundo do contexto dos educandos e que, quando trabalhados no ambiente escolar e em sala de aula por meio da abordagem temática freireana, proporcionam interesse e significado de aprendizagem para os sujeitos e para o professor, como vem sendo apontado por trabalhos como Fonseca (2019), Maraschin (2019) e Paniz e Muenchen (2020).

A compreensão limitada dos licenciandos indica que o Estágio Curricular I é visto como um treinamento para o Estágio Curricular II, esperando que esse preparo se dê no planejamento repetitivo de aulas. Assim, a situação-limite percebida foi a compreensão limitada sobre planejamento de aulas que os estagiários demonstraram naquele momento da formação inicial, pois só entendiam uma forma de fazer estágio, influenciada por uma cultura escolar arraigada no ensino tradicional. Em vista disso, durante a realização da pesquisa, buscou-se indicar formas de superar tal situaçãolimite, o que ocorreu em duas vertentes: a primeira pela construção de um processo formativo que auxiliasse a romper com essa visão simplista, por meio do diálogo e problematização; a segunda pela compreensão de que professores formadores precisam proporcionar condições para os alunos perceberem e vivenciarem possibilidades para ensinar e aprender de forma diferente das antes realizadas.

Por considerar o diálogo "uma exigência existencial" dos homens (Freire, 2019), a tensão analisada viabilizou a essência de um momento dialógico em sala de aula, em que o formador em formação pôde repensar suas ações e proporcionar aos licenciandos problematizar suas percepções em busca de significação.

O diálogo proporcionou a quebra de um silêncio que (re)significou a prática docente. Ao perceber a dificuldade na compreensão de que estar na escola e conhecer sobre o contexto de atuação é um aspecto relevante para o planejamento de aula, precisou-se construir o conhecimento de que o Estudo da Realidade não é uma 
“atividade de campo" com fim nela mesma, mas é uma possibilidade de voltar o olhar para questões da realidade dos sujeitos e tratá-las como parte do processo de ensino e forma de planejamento, ou seja, perceber a sensibilização do olhar docente para questões que muitas vezes não estão postas no currículo escolar, pois o saber planejar uma aula ultrapassa o campo teórico e a repetição de planos de aulas como comprovação do saber fazer. Para além disso, o movimento de estudar a realidade contribuiu para ampliar a compreensão da intencionalidade da educação na perspectiva crítica, que não é minimizar a parte conceitual do currículo, mas sim, subordinar os conteúdos a uma temática relevante para a comunidade escolar, a fim de que, em alguma medida, seja capaz de contribuir com sua transformação. Nesse contexto de formação, têm-se contribuições de Paniz et al. (2018), que vêm destacando a relevância de considerar a realidade no desenvolvimento de currículos mais críticos e reflexivos.

O diálogo e a problematização presentes no processo formativo possibilitaram uma compreensão consciente do Estudo da Realidade como um momento de planejamento e formação para os estagiários. Esses conhecimentos foram sendo demonstrados quando os estagiários começaram a estabelecer relações entre a vivência na escola e os conteúdos que poderiam ser trabalhados em aulas e, dessa forma, foram se assumindo protagonistas em planejar aulas que buscassem solucionar aqueles "problemas" identificados no Estudo da Realidade. Esse aspecto pode ser melhor percebido na narrativa a seguir:

[...] - Professora, agora conversando com os colegas e prestando mais atenção nas falas do Estudo da Realidade dá para perceber que há uma falta de comunicação entre os setores da comunidade escolar né?! (L5).

- Verdade! Exclama outro estagiário. Há uma dicotomia entre as falas da gestão e professores, por exemplo, quanto à liberação da rede de internet na escola. (L6)

- Os pais também falam que falta contato com a escola, menciona outro estagiário. (L7)

- Então me parece que se tem um problema de comunicação, estamos identificando uma ausência de diálogo no espaço escolar! Vamos seguir analisando e estabelecendo essas ligações na nossa "rede temática", para vermos as situações significativas que vão aparecendo? (F1)

"Nesse momento estávamos discutindo a respeito das falas significativas referente a vivência do Estudo da Realidade na escola, e pensando o planejando... Até que percebo:

— Já está no horário de finalizarmos nossa aula, e ainda temos tanto a conversar!”. (F1)

— Passou tão rápido a tarde! Exclamou um estagiário. (L8) 
- Vamos seguir com o planejamento em grupo na próxima aula? Está interessante professora! (L9)

Foi então que notei a turma envolvida. Caminhando na sala atenta as falas entre os estagiários, percebi que a vivência na escola, quando dialogada e problematizada começou fazer sentido, e eles estavam comprometidos a planejar aulas que ajudassem resolver o problema escolhido daquela comunidade escolar que denominamos de Tema Significativo. (F1) [...] (Tadeu, 2018, p. 72-73).

Assim, constatou-se que inserir princípios freireanos em processos de formação inicial de professores, seja como componente curricular, seja em momentos pontuais em intervenções de ensino, é uma possibilidade de trabalhar a realidade em aula. Além disso, evidenciou-se que esses princípios auxiliam o distanciamento de uma visão propedêutica, fragmentada e exclusivamente conteudista de currículo.

\section{A escolha de temas na educação básica orientada pelo contexto}

A pesquisa desenvolvida por Maraschin (2019) utilizou-se da Abordagem Temática a partir da aproximação com as etapas da Investigação Temática em um movimento de codificação-problematização-descodificação (Delizoicov, 1991; Freire, 2019). Ela se aproximou de algumas discussões realizadas por Centa e Muenchen (2016), que, ao buscarem por temas a serem discutidos no Ensino de Ciências, destacaram a necessidade de refletir sobre os papéis do educador e dos educandos na constituição de cidadãos que percebem suas realidades e traçam perspectivas para o futuro da sociedade, baseadas em atitudes conscientes e transformadoras, pois “[...] não adianta $o$ currículo ser visto como uma lista de conteúdos a serem vencidos, deve-se considerar os problemas locais para a seleção dos conhecimentos [...]" (Centa \& Muenchen, 2016, p. 282). Portanto, nesta subseção, buscar-se-á apresentar a importância do contexto para a organização curricular da educação básica, com base nos argumentos apresentados até aqui e também a partir da experiência vivenciada neste trabalho.

Durante os diálogos ocorridos em sala, o professor-pesquisador evidenciou junto aos alunos a codificação leite/dinheiro (Maraschin, 2019). A seguir, apresenta-se um fragmento que corresponde a esses diálogos e que retrata a situação-limite observada. Essa situação-limite foi identificada por meio dos diálogos em sala de aula, sendo percebida pelas falas a seguir. Antes, destaca-se que, para preservar a identidade dos participantes, o professor-pesquisador foi representado pela letra "P", e os alunos, pela letra "A" seguida de um número:

Tá, tirei o leite e botei no refrigerador. E agora? (P)

Aí vem o caminhão. [...] (A2).

E o cara do caminhão confere a temperatura? $(\mathrm{P})$

Sim. E mais a amostra, ainda, que eles têm um frasquinho. Ele recolhe o leite, aquela amostra e leva. [...]. Para fazerem os testes (A2). 
No caminhão o leite todo mistura, então eles tiram as amostras para fazer os testes das bactérias e qualidade, mamite $^{3}$ (A8).

Porque se o teu leite estragar o dos outros... (A7).

Tu paga todo o caminhão, todo o teu tanque, pois o caminhão tem geralmente de três a quatro tanques. [...] (A2).

E na hora eles te dizem que não vão levar? (P)

É. Aí tu tens as opções: ou tu pega todo aquele leite, faz queijo ou doce e te vira; ou senão tu só abre a boca do freezer e deixa a campo (A2).

Se a vaca estiver com antibiótico também dá problema (A10).

Aí uma vaca com antibiótico estraga um freezer de mil ou dois mil litros. [...] (A2).

E já deu algum problema para vocês, de não poder mandar o leite? (P)

Já (A2).

Na greve dos caminhões não mandamos (A3).

E por problemas com o leite, por estar mais ácido ou contaminado? [...] (P)

Já deu problema (P2) (Maraschin, 2019, p. 47-49, grifo nosso).

Tendo identificado os problemas apontados pelos discentes, reconhece-se como situação-limite a visão limitada sobre a potencialidade da fonte de renda no que diz respeito ao melhor aproveitamento do leite, em sua totalidade, quando este se encontra inapropriado para envio às empresas. Quanto a esse aproveitamento, a possibilidade de superação da situação-limite surgiu a partir de um dos objetivos de ensino, que foi a produção e apresentação de um seminário dividido em quatro grupos de derivados do leite (iogurte, nata, queijo e ambrosia), propondo formas de seu beneficiamento na produção dos derivados, que fossem explicadas a partir dos conhecimentos culturais (receitas e experiências familiares e/ou da comunidade), dos conceitos químicos que emergiram a partir da temática construída e que foram trabalhados em aula (norteados pela reflexão sobre o contexto local, estando envolvidos na produção dos derivados) e de um planejamento financeiro que gerasse renda extra para as famílias (perspectivas futuras para microempresas, normas sanitárias etc.).

Como resultados, foi possível perceber que os educandos conseguiram apropriarse de muitas evidências construídas coletivamente, adquirindo novas visões sobre a disciplina e sobre o tema que faz parte do seu cotidiano. A fala a seguir explicita esse aspecto:

3 Mastite ou mamite: inflamação na glândula mamária, causada por bactérias. 
A gente nunca para pra pensar sobre a Química por trás das coisas e a gente aprendeu a Química por trás de um doce. [...]. Depois a gente acabou fazendo a mesma coisa no trabalho: nos perguntamos como iríamos manter a nossa produção, como iríamos higienizar as coisas, era mais ou menos o mesmo papo, então tudo se integrou no final e fez sentido (A4) (Maraschin, 2019, p. 86).

Também, considera-se que foi possível conhecer algumas perspectivas quanto ao contexto histórico, social e econômico da comunidade. A proposta contribuiu para que os envolvidos passassem a perceber novos caminhos de transformação das suas realidades, pois muitos pensaram sobre como melhorar sua fonte de renda ou até mesmo em buscar novas oportunidades de crescimento pessoal e profissional. No que se refere a melhorar suas fontes de renda, manifestações em relatos verbais aconteceram, como: "a gente possui a matéria prima, então parece possível/rentável produzir queijo", ou ainda, "ao fazer os cálculos para custos de produção do nosso derivado, vimos que este é uma possível fonte de renda extra e viável, fato que não tínhamos percebido antes”.

Além disso, quanto à busca por novas oportunidades, em contato recente com alguns desses educandos, foi relatado ao pesquisador que eles passaram a refletir sobre os diálogos e problematizações dos encontros, fator que fez com que buscassem cursar um ensino superior para entender outros aspectos da sua localidade e atender a demandas locais. Destaca-se, por exemplo: Licenciatura em História, com o intuito de compreender melhor o contexto histórico daquela realidade e as transformações ocorridas; Medicina Veterinária, na intenção de manter os cuidados com os animais de suas propriedades e dos vizinhos; e Bacharelado em Direito, visando conhecer aspectos legais, principalmente das localidades de assentamentos. Segundo relatos dos docentes da escola, que já conheciam esses educandos há mais tempo, muitos não desejavam seguir estudando e ficavam satisfeitos com a vida e o trabalho no campo.

Alguns resultados sobre a práxis também se mostraram. Ao refletir a prática realizada, o pesquisador passou a perceber, como limitação à proposta e à educação básica, o caráter individual. Tal processo não ocorreu em equipe, mesmo sendo uma adaptação da Investigação Temática, configurando-se como uma intervenção pontual. Abordagens nesse viés necessitam de compromisso e disposição para o diálogo por parte de docentes de diferentes áreas, visto que precisam abandonar suas zonas de conforto, passando a ser orientados por um processo investigativo, que não gera respostas imediatas. O que será ensinado dependerá do tema encontrado, da singularidade da realidade pesquisada e das subjetividades dos sujeitos envolvidos. Mesmo com a realização dessa ação isolada, não há como descaracterizar sua relevância, já que o trabalho apresentado aproximouse de referenciais que propõem práticas dialógicas, contrariando concepções bancárias (Freire, 2019).

Por fim, essa abordagem apresenta-se como uma possibilidade para buscar a superação de uma situação-limite identificada por meio do diálogo e da problematização no contexto de ensino, já que alguns conhecimentos sistematizados da Ciência foram trabalhados no sentido de auxiliar a compreensão de aspectos da realidade e permitiram 
vislumbrar possibilidades de mudança de práticas. Reforça-se, nesta experiência, que as estratégias de ensino também contribuíram para que isso fosse possível, uma vez que dialogam com as categorias freireanas citadas anteriormente e permitem ampliar os espaços para além da sala de aula, considerando saberes da comunidade e saberes da prática rural. Além disso, a pesquisa orientada em grupo permitiu o resgate sobre algumas práticas culturais, através da produção de derivados de leite, evitando seu descarte, assim como a reflexão sobre aspectos da Ciência, abordados em aula.

\section{Considerações finais}

Buscou-se, neste estudo, problematizar algumas situações-limite tanto na formação de professores quanto no Ensino de Ciências. As situações-limite identificadas permitiram perceber limitações no processo formativo de professores, em caráter inicial e em atuação, e também durante a aprendizagem em Química na educação básica. Foi possível sinalizar percepções limítrofes de professores de Ciências, relacionadas a sua própria prática pedagógica, bem como em relação ao contexto de atuação. Estão próximas ao que Silva et al. (2016) denominaram de situações-limite de dimensão pedagógica e acerca da percepção da realidade, já que as professoras identificaram como importante a abordagem da temática agrotóxico para o contexto em que a comunidade escolar se insere, porém, ainda permanecem ausentes essas discussões em aula e a organização de propostas com a dimensão temática. Além disso, percebem o contexto de uma forma limitada, desconsiderando que uma análise ou discussão em torno de um tema possa nortear a organização curricular. Esses aspectos contribuem para manter uma postura passiva, constituindo uma cultura do silêncio (Freire, 2019) em relação ao trabalho pedagógico e no Ensino de Ciências.

Em relação ao processo formativo desenvolvido na formação inicial, destaca-se a situação-limite pedagógica acerca das compreensões sobre planejamentos de aula que os licenciandos demonstraram possuir, muito característico do que Carvalho (2012) identifica como visão simplista, aquela que os professores em formação já possuem em sua bagagem cultural, com forte influência de uma escolarização pautada no modelo tradicional. A busca pela superação desta situação-limite durante a pesquisa deu-se pela intenção de romper com a visão simplista, por meio de um processo formativo dialógico e problematizador, bem como a (re)significação da prática docente dos formadores, que possibilitou a percepção de que é necessário que os estagiários se apropriem, por meio de vivências, de outras formas de ensinar e aprender. Nesse sentido, os princípios freireanos, quando presentes na formação inicial, contribuem para problematizar a realidade em sala de aula, assim como possibilitam uma formação mais crítica, distanciando-se da concepção propedêutica e conteudista de currículo, aspectos que contribuem para a superação da compreensão simplista de formação.

A situação-limite, no contexto da sala de aula da educação básica apresentada neste trabalho, pôde ser evidenciada pelas falas dos educandos, quando eles tiveram a oportunidade de manifestar seus conhecimentos e práticas, oportunizando a sua 
problematização e permitindo o vislumbre do inédito-viável, ou seja, percebendo outras formas de "tratar" tal situação naturalizada nas práticas comunitárias. Nesse sentido, como possibilidade para superá-las no campo educacional, Freire (2019) estimula o exercício de reflexão sobre a própria prática, denominado nesse campo como práxis educativa, que busca a ressignificação de pensamentos e ações dos sujeitos pela articulação entre os conhecimentos trazidos por alunos e professores, visando à compreensão dos compromissos históricos, culturais, sociais, políticos e econômicos do cidadão na sociedade. Os argumentos anteriores corroboram com Marques et al. (2020, p. 444), que defendem um currículo "[...] que integre elementos das diferentes culturas, que auxilie o educando a repensar os problemas sociais de forma crítica e o instrumentalize para a participação social". Isso permite envolver os educandos no seu processo formativo, tornando-os ativos em sua aprendizagem e levando-os ao entendimento de que a escola pode e deve preocupar-se com o contexto na qual está inserida.

Diante do exposto, por meio de três contextos diferentes de pesquisa, argumentase a favor de um Ensino de Ciências que considere os problemas locais na organização das práticas educativas, as quais podem auxiliar na compreensão e transformação de situações que envolvem contradições sociais presentes no contexto. O trabalho com questões da realidade está relacionado a uma perspectiva de transformação, superando uma simples menção ao contexto como forma de ilustração dos conteúdos. Além disso, é possível dizer que os estudos aqui discutidos, em alguma medida, reforçam as discussões já realizadas na área, em relação à formação de professores nos processos de pensar e fazer currículos, articulados às problemáticas locais, como apontam os estudos de Silva et al. (2016) e Rocha (2013). Sinaliza-se a importância da constituição de coletivos de formação, tanto em caráter inicial quanto em processos formativos pontuais, bem como a inclusão dessas questões em grupos de estudos, integrando gestão e coordenação pedagógica.

Em relação ao que vem sendo apresentado sobre as situações-limite (Rocha, 2013; Silva et al., 2016; Freitas \& Queirós, 2020a), esse trabalho, ainda que em uma dimensão teórica, possibilita pensá-las como elemento que legitima contradições e problemáticas na prática docente, que podem ser problematizadas. Portanto, como dito, para que elas sejam transcendidas, devem estar localizadas como elo entre o diálogo e a problematização, visto que a partir do diálogo as situações começam a emergir, para só então serem problematizadas e superadas. Considerando os trabalhos de Fonseca (2019), Tadeu (2018) e Maraschin (2019), evidenciou-se que as situações-limite não necessitam, obrigatoriamente, seguir rigorosamente todas as etapas de Investigação Temática para serem percebidas. Portanto, é importante considerar, enquanto incursões futuras: Como as situações-limite podem contribuir para a obtenção de temas sem a realização do processo de Investigação Temática, tendo em vista que essas constituem contradições sociais? Nesse sentido, a aproximação dos contextos escolares com a Universidade, por exemplo, pode constituir-se como via que possibilita a identificação de situações-limite e o aprofundamento de suas discussões. 
Sobre a Universidade, ratifica-se a necessidade evidenciada a partir das discussões apontadas pelos trabalhos de Nascimento e Von Linsingen (2006), Muenchen e Auler (2006), Bomfim (2018) e Freitas e Queirós (2020b), que indicaram, em seus resultados, o papel fundamental da formação de professores para a superação do currículo linear e segmentado por disciplinas. Essa necessidade foi confirmada a partir dos três trabalhos apresentados: no primeiro, pela visão limítrofe evidenciada e a necessidade de seguir as ementas previstas; no segundo, pela visão limitada dos estagiários, que valorizavam a mecanização de técnicas ao invés do planejamento pedagógico, que considera a realidade da escola; e no terceiro, pela realização de uma prática isolada na educação básica, que não ocorre com frequência no fazer pedagógico de outros licenciandos e tampouco de professores que atuam há mais tempo no contexto escolar. A abordagem de temas no ensino de Ciências precisa garantir um trabalho dialógico, interdisciplinar e que considere o contexto no qual o educador e os educandos estão inseridos. Argumenta-se sobre a importância dessas investigações na Educação em Ciências do ponto de vista curricular, pois a visão adotada não deve ser metodológica, mas sim, de estruturação de currículos, compromisso que precisa ser discutido e encorajado desde a formação inicial até aquelas de caráter formativo.

Os princípios freireanos (diálogo e problematização) permitem pensar práticas pedagógicas nesse viés. Destaca-se que articular processos educativos nessa perspectiva torna-se um desafio, haja vista a estrutura curricular já naturalizada nos espaços escolares e as concepções pedagógicas dos professores. Por isso, reforça-se que a abordagem de temas apresenta possibilidades de articular processos de ensino contextualizados, considerando aspectos presentes na realidade e situações significativas para os sujeitos, sem descartar o conhecimento sistematizado, mas de forma que dialoguem entre si. Por fim, sinaliza-se, como necessidade de trabalhos para a área, o estudo dessas articulações a processos formativos de professores, como potencialidade para discutir e planejar propostas nesse sentido.

\section{Referências}

Almeida, E. S., \& Gehlen, S. T. (2019). Organização curricular na perspectiva Freire-Cts: propósitos e possibilidades para a educação em ciências. Ensaio: Pesquisa em Educação em Ciências (Online), 21, 1-24. https://doi.org/10.1590/1983-21172019210126

Alves, A. H. B., \& Silva, A. F. G. (2015). Manifestações de Obstáculos Gnosiológicos para a Seleção de Conteúdos na Implementação de um Currículo Crítico em Ciências Naturais. Alexandria: Revista de Educação em Ciência e Tecnologia, 8(1), 181-207. https://doi.org/10.5007/1982-5153.2015v8n1p181

Araújo, L. B. (2015). Os Três Momentos Pedagógicos como estruturantes de currículos. (Dissertação de Mestrado, Universidade Federal de Santa Maria, Santa Maria, Rio Grande do Sul). Repositório Digital da UFSM. http://repositorio.ufsm.br/handle/1/6692 
Auler, D. (2018). Cuidado! Um cavalo viciado tende a voltar para o mesmo lugar. Appris. Becker, F. (1995). Epistemologia do professor: o cotidiano da escola. Vozes.

Bicudo, M. A. (2011). Análise fenomenológica estrutural e variações interpretativas. In M. A. Bicudo (org.) Pesquisa qualitativa segundo a visão fenomenológica ( $1^{\text {a }}$ ed., pp. 53-74). Cortez.

Bomfim, M. G. (2018). Opotencial gnosiológico da abordagem temática freiriana: um olhar sobre o processo formativo de professores da EJA. (Dissertação de Mestrado, Universidade Estadual de Santa Cruz, Ilhéus, Bahia). Biblioteca Digital de Teses e Dissertações UESC. http://www.biblioteca.uesc.br/biblioteca/bdtd/201610059D.pdf

Brick, E. (2017). Realidade e Ensino de Ciências. (Tese de Doutorado, Universidade Federal de Santa Catarina, Florianópolis, Santa Catarina). Repositório Institucional da UFSC. https://repositorio.ufsc.br/xmlui/handle/123456789/182727

Carvalho, A. M. P. (2012). Os estágios nos cursos de licenciatura. Cengage Learning.

Centa, F. G. (2015). Arroio Cadena: Cartão Postal de Santa Maria? Maria?": Possibilidades e Desafios em uma Reorientação Curricular na perspectiva da Abordagem Temática. (Dissertação de Mestrado, Universidade Federal de Santa Maria, Santa Maria, Rio Grande do Sul). Repositório Digital da UFSM. https://repositorio.ufsm.br/handle/1/6748

Centa, F. G., \& Muenchen, C. (2016). O Despertar para uma Cultura de Participação no Trabalho com um Tema Gerador. Alexandria: Revista de Educação em Ciência e Tecnologia, 9(1), 263-291. https://doi.org/10.5007/1982-5153.2016v9n1p263

Coelho, J. C. (2005). A chuva ácida na perspectiva de tema social: um estudo com professores de Química em Criciúma (SC). (Dissertação de Mestrado, Universidade Federal de Santa Catarina, Florianópolis). Respositório Institucional da UFSC. https://repositorio.ufsc. br/handle/123456789/101912

Connelly, M., Clandinin, J. (1995). Relatos de experiencia e investigación narrativa. In J. Larrosa, R. Arnaus, V. Ferrer, N. P. de Lara, M. Connelly, J. Clandinin, \& M. Greene (orgs.) Déjame que te cuente: Ensayos sobre narrativa y educación (1ª ed., pp. 11-59). Laertes.

Delizoicov, D. (1991). Conhecimento, tensões e transições. (Tese de Doutorado, Universidade Federal de São Paulo, São Paulo, São Paulo). Repositório Institucional da UFSC. https://repositorio.ufsc.br/handle/123456789/75757

Delizoicov, D., Angotti, J. A., \& Pernambuco, M. M. (2011). Ensino de ciências: fundamentos e métodos ( $4^{\mathrm{a}}$ ed.). Cortez.

Denzin, N., \& Lincoln, Y. (2006). O planejamento da pesquisa qualitativa: teorias e abordagens. Artmed. 
Ferreira, M. V., Muenchen, C., \& Auler, D. (2019). Desafios e potencialidades em intervenções curriculares na perspectiva da abordagem temática. Ensaio: Pesquisa em Educação em Ciências, 21, 1-22. https://doi.org/10.1590/1983-21172019210108

Fonseca, E. M. (2019). Abordagem de temas no ensino de ciências: reflexões para processos formativos de professores. (Dissertação de Mestrado, Universidade Federal do Pampa, Bagé, Rio Grande do Sul). Repositório Institucional da Unipampa. http://dspace. unipampa.edu.br:8080/jspui/handle/riu/4593

Fonseca, E. M., \& Lindemann, R. H. (2020). Temática Agrotóxico na Prática Pedagógica de Professoras de Ciências: Das Compreensões às Possibilidades de Intervenção. Revista Brasileira de Pesquisa em Educação em Ciências, 20(u), 1307-1337. https://doi. org/10.28976/1984-2686rbpec2020u13071337

Freire, P. (2019). Pedagogia do oprimido (71 a ed.). Paz e Terra.

Freitas, W. P. S. de, \& Queirós, W. P. de (2020a). A politização docente para o enfrentamento de uma situação-limite por meio de intervenções didáticas pautadas na perspectiva Giroux-CTS. Investigações em Ensino de Ciências, 25(2), 293-312. https:// doi.org/10.22600/1518-8795.ienci2020v25n2p293

Freitas, W. P. S. de, \& Queirós, W. P. de (2020b). O uso de audiovisuais problematizadores no processo de investigação temática como meio para obtenção do tema gerador. Revista Ensaio, 22(e14884), 1-20. https://doi.org/10.1590/21172020210121

Giacomini, A., \& Muenchen, C. (2016). Avanços alcançados por professores na implementação da abordagem temática em uma escola pública estadual do interior do RS. Educação em Revista, 32(3), 189-216. https://doi.org/10.1590/0102-4698136042

Halmenschlager, K. R. (2011). Abordagem temática no ensino de ciências: algumas possibilidades. Vivências, 7(13), 10-21. http://www2.reitoria.uri.br/ vivencias/ Numero_013/artigos/artigos_vivencias_13/n13_01.pdf

Halmenschlager, K. R., \& Delizoicov, D. (2017). Abordagem Temática no Ensino de Ciências: Caracterização de Propostas Destinadas ao Ensino Médio. Alexandria, 10 (2), 305-330. https://doi.org/10.5007/1982-5153.2017v10n2p305

Lei no 9394, de 20 de dezembro de 1996. Estabelece as diretrizes e bases da Educação Nacional. Brasília: MEC. http://www.planalto.gov.br/ccivil_03/Leis/L9394.htm

Maraschin, A. A. (2019). Problematização do cotidiano de estudantes da zona rural no contexto do Residência Pedagógica: a temática leite e o ensino de Química. (Trabalho de Conclusão de Curso, Universidade Federal do Pampa, Bagé, Rio Grande do Sul). Repositório Institucional da Unipampa. http://dspace.unipampa.edu.br:8080/jspui/ handle/riu/4852

Marques, S. G., Paniz, C. M., Klein, S. G., Saúl, T. S., \& Muenchen, C. (2020). A inserção da abordagem temática na educação básica: um olhar sobre o currículo. Currículo sem fronteiras, 20(2), 442-458. http://dx.doi.org/10.35786/1645-1384.v20.n2.05 
MEC (Ministério da Educação) (2013). Diretrizes Curriculares Nacionais Gerais da Educação Básica. http://portal.mec.gov.br/index.php?option=com_ docman \&view $=$ download \&alias $=13448$-diretrizes-curiculares-nacionais-2013pdf\&Itemid $=30192$

MEC (Ministério da Educação) (2017). Base Nacional Comum Curricular. http:// basenacionalcomum.mec.gov.br/images/BNCC_EI_EF_110518_versaofinal_site.pdf

Moraes, R. \& Galiazzi, M. C. (2016). Análise textual discursiva (3ª ed). Unijuí.

Muenchen, C., \& Auler, D. (2007). Configurações curriculares mediante o enfoque CTS: desafios a serem enfrentados na Educação de Jovens e Adultos. Ciência \& Educação, 13(3), 421-434. https://doi.org/10.1590/S1516-73132007000300010

Muenchen, C., \& Delizoicov, D. (9-12 de setembro de 2013). Concepções sobre problematização na educação em ciências. IX Congreso Internacional sobre Investigación en Didáctica de las Ciencias, Girona, Espanha. https://www.raco.cat/index.php/ Ensenanza/article/view/307891/397859

Muenchen, C., \& Delizoicov, D. (2014). Os três momentos pedagógicos e o contexto de produção do livro "Física". Ciência \& Educação, 20(3), 617-638. https://dx.doi. org/10.1590/1516-73132014000300007

Nascimento, T. G., \& Von Linsingen, I. (2006). Articulações entre o enfoque CTS e a pedagogia de Paulo Freire como base para o ensino de ciências. Convergência, 13(42), 95-116.

Paniz, C. M., Centa, F. G., Araújo, L. B., \& Muenchen, C. (2018). Os três momentos pedagógicos como estruturantes de currículos: o estudo da realidade e os temas geradores na educação em ciências. Reflexão e Ação. Santa Cruz do Sul, 26(2), 249-266. https:// online.unisc.br/seer/index.php/reflex/article/view/8945

Paniz, C. M., \& Muenchen, C. (2020). O estudo da realidade e os temas geradores no ensino de ciências: reflexões sobre um processo vivenciado no contexto do PIBID. ENCITEC: Ensino de Ciências e Tecnologia em Revista, 10(1), 56-72. http://dx.doi. org/10.31512/encitec.v10i1.3028

Possamai, L. (2018). A pesquisa-ação como estratégia metodológica para os temas geradores nos pressupostos freireano. In N. C. Delizoicov, G. M. Stuani, \& S. L. Cunha, (org). A atualidade das ideias de Paulo Freire (pp. 303-334). Vivens.

Ricardo, E. C. (2010). Problematização e contextualização no ensino de física. In A. M. P. de Carvalho, E. C. Ricardo, L. H. Sasseron, M. L. V. dos S. Abib, \& M. Pietrocola (orgs.) Ensino de Física (1 aed., pp. 29-47). Cengage Learning.

Rocha, A. L. F. (2013). A possibilidade de uma abordagem crítica no ensino de zoologia: das situações-limite à práxis pedagógica (Dissertação de mestrado, Universidade Federal de Santa Catarina, Florianópolis, Santa Catarina). Repositório Institucional da UFSC. 
https://repositorio.ufsc.br/handle/123456789/107394

Roso, C. C., Santos, R. A., Rosa, S. E., \& Auler, A. (2015). Currículo temático fundamentado em Freire-CTS: engajamento de professores de física em formação inicial. Revista Ensaio: Pesquisa em Educação em Ciências, 17(2), 372-389. https://doi. org/10.1590/1983-21172015170205

Silva, R. M., Solino, A. P., Sousa, P. S., Fonseca, K. N., Novais, E. S. P., Gehlen, S. T. (2016). Situações-limite na formação de professores de ciências na perspectiva freireana: da percepção da realidade à dimensão pedagógica. Investigações em Ensino de Ciências, 2(3), 127-151. http://dx.doi.org/10.22600/1518-8795.ienci2016v21n3p127

Schneider, T. M., Paniz, C. M., Magoga, T. F., Ferreira, M. V., \& Muenchen, C. (2018). Os três momentos pedagógicos e a abordagem temática na educação em ciências: um olhar para as diferentes perspectivas. Ensino \& Pesquisa, 16(1), 150-172. http://periodicos. unespar.edu.br/index.php/ensinoepesquisa/article/view/1286/1339

Stake, R. (2011). Pesquisa qualitativa: estudando como as coisas funcionam. Penso.

Tadeu, T. S. A. (2018). Sensibilizando o olhar docente através de estratégias dialógicas problematizadoras na formação inicial em Química. (Dissertação de Mestrado, Universidade Federal do Pampa, Bagé, Rio Grande do Sul). Repositório Institucional da Unipampa. http://dspace.unipampa.edu.br:8080/jspui/handle/riu/4596

Tardif, M. (2000). Saberes profissionais dos professores e conhecimentos universitários: elementos para uma epistemologia da prática profissional dos professores e suas consequências em relação à formação para o magistério. Revista Brasileira de Educação, 13, 5-24. http://www.ergonomia.ufpr.br/Metodologia/RBDE13_05_MAURICE_ TARDIF.pdf 
Eril Medeiros da Fonseca

Universidade Federal do Pampa Grupo de Pesquisa G.A.M.A (Grupo de Pesquisa sobre Aprendizagens, Metodologias e Avaliação) Bagé, Rio Grande do Sul, Brasil erilmf@gmail.com

Tassiéllen Soares Antunes Tadeu

Universidade Federal do Pampa Bagé, Rio Grande do Sul, Brasil tassi.bg@gmail.com

André de Azambuja Maraschin

Universidade Federal do Pampa Grupo de Pesquisa G.A.M.A (Grupo de Pesquisa sobre Aprendizagens, Metodologias e Avaliação) Bagé, Rio Grande do Sul, Brasil andremaraschin@hotmail.com

\section{Renata Hernandez Lindemann}

Universidade Federal do Pampa Grupo de Pesquisa G.A.M.A (Grupo de Pesquisa sobre Aprendizagens, Metodologias e Avaliação)

Bagé, Rio Grande do Sul, Brasil renatalindemann@unipampa.edu.br

Editora Responsável

Stefannie Ibraim

\footnotetext{
Manifestação de Atenção às Boas Práticas Científicas e de Isenção de Interesse

Os autores declaram ter cuidado de aspectos éticos ao longo do desenvolvimento da pesquisa e não ter qualquer interesse concorrente ou relações pessoais que possam ter influenciado o trabalho relatado no texto.
} 